\title{
Tracing circulating fluids in gas shales using noble gases and nitrogen
}

\author{
S.BASU ${ }^{*}$, A.B. VERCHOVSKY ${ }^{2}$, A.P. JONES ${ }^{1}$, D. \\ PAPINEAU ${ }^{1}$ AND R. ANTWI ${ }^{1}$
}

${ }^{1}$ University College London, 5 Gower Street, UK, WCIE6BS

(*correspondence: sudeshna.basu@ucl.ac.uk)

${ }^{2}$ School of Physical Sciences, The Open University, Milton

Keynes, MK7 6AA, UK (sasha.verchovsky@open.ac.uk)

Noble gases occur as free, adsorbed or dissolved components in shale. Nitrogen in shale occurs as a major constituent of organic matter or, can be adsorbed or fixed in the lattice of K-bearing clay minerals. Together, they can be used to trace gas loss/retention from shales. We measured $\mathrm{He}$, $\mathrm{Ne}, \mathrm{Ar}$ and $\mathrm{N}_{2}$ concentration, $\delta^{15} \mathrm{~N}$ and ${ }^{40} \mathrm{Ar} /{ }^{36} \mathrm{Ar}$ isotopic ratios, along with ${ }^{4} \mathrm{He}^{/ 40} \mathrm{Ar}^{*}$ (where ${ }^{40} \mathrm{Ar}^{*}$ is radiogenic ${ }^{40} \mathrm{Ar}$ ), ${ }^{20} \mathrm{Ne} /{ }^{36} \mathrm{Ar}$, ${ }^{20} \mathrm{Ne} / \mathrm{N}_{2}$ and ${ }^{36} \mathrm{Ar} / \mathrm{N}_{2}$ from two well-preserved cores of Haynesville-Bossier formation, deposited during 156-145.5 Ma in the East Texas Basin [1]. The cores are wellcharacterised for their carbon isotopic composition [2,3]. Seven samples from 3540-3726 m of core 2 and five from $3490-3540 \mathrm{~m}$ of core 3 were analysed, the cores retrieved from wells about $220 \mathrm{~km}$ apart.

The ${ }^{40} \mathrm{Ar} /{ }^{36} \mathrm{Ar}$ ratios in both the cores are correlated with depth and range from atmospheric to ratios up to $\sim 4000$ indicating mixing between the atmospheric and the crustal components. The $\mathrm{N}$ concentration in core 2 varies between $300-750 \mathrm{ppm}$ and $\delta^{15} \mathrm{~N}$ between +1 and $+8 \%$. The total $\mathrm{N}$ concentration in core 3 is higher $(900-1400 \mathrm{ppm})$ and $\delta^{15} \mathrm{~N}$ is lower and less variable $(\sim-2$ to $+0.3 \%)$. The ${ }^{36} \mathrm{Ar} / \mathrm{N}_{2}$ ratio in both the cores increases with depth, along with the ${ }^{36} \mathrm{Ar}$ concentration that, cannot be attributed to mechanical compaction during burial. The measured porosity in both the cores increases with depth as a consequence of mineral dissolution and/or precipitation or, related to the occurrence of over pressured zone. The thermal maturity of organic matter determined using Raman spectra also suggests a decrease with increasing depth. Hence, noble gases can be potentially used to track under compacted, over pressured zone in a hydrocarbon formation.

[1] Basu et al. (2020) J. Mar. Sci. Eng. 8(2), 136; https://doi.org/10.3390/jmse8020136 [2] Basu et al. (2018) Energy Procedia 146, 47-52. [3] Basu et al. (2019) Front. Earth Sci. 7, Article 297; https://doi.org/10.3389/feart.2019.00297 